\title{
Implementasi Strategi Pemasaran Jasa Pendidikan pada Masa Pandemi Covid-19 di SMK Muhammadiyah Pagar Alam
}

\author{
Ade Wulandari ${ }^{1}$, Kasinyo Harto ${ }^{2}$, Mardiah Astuti ${ }^{3}$, Ari Sandi ${ }^{4}$ \\ 1,2,3,4 Universitas Islam Negeri Raden Fatah Palembang, Indonesia \\ adewulan1997@gmail.com \\ masyo_71@yahoo.com \\ mardiahastuti_uin@radenfatah.ac.id \\ arisandi@radenfatah.ac.id
}

\begin{abstract}
The aim of this study was to describe and to analyze factors which the implementation of educational service marketing strategi. The type of research used is field research using a qualitative method. The data collection instrument was carried out by interview, observation dan documentation. The informants are participal, assistant prancipal of academic and student affairs, promotion team, educational consumer (society). Data sources are used in the form of primer and secondary data. Research result indicates that the implementation of educal service marketing strategy during covid-19 pandemic in SMK Muhammadiyah Pagar Alam which focuses on positioning activity (decide marketing position) indicate that this implementation has been well implemented. It can be seen from seceral indicators which are fulfilled in implementation of educational service marketing strategy on positioning activity that are educational institution provide marketing attribute or media, institution describes good prospect for alumnus and gives valid information related to aducational fee on educational marketing activity. Supporting factors of positioning activity are educational background of teachers and staff, sufficient facilities and infrastructure, strategic school location that is easy to be reached by educational consumer. While inhibiliting factors are price regulation or educational fee and process of educational product offers.
\end{abstract}

Keyword: educational service marketing, positioning strategy 


\begin{abstract}
ABSTRAK
Penelitian ini bertujuan menganalisis Implementasi Strategi pemasaran jasa pendidikan pada masa pandemi Covid-19 serta menganalisis faktor yang mempengaruhi Implementasi Strategi pemasaran jasa pendidikan pada masa pandemi Covid-19 di SMK Muhammadiyah. Penelitian menggunakan metode deskriptif kualitatif. Teknik pengumpulan data dilakukan melalui kegiatan observasi, wawancara dan dokumentasi. Sumber data dalam penelitian ini berupa sumber data primer dan sumber data sekunder. Hasil penelitian menunjukkan bahwa implementasi strategi pemasaran jasa pendidikan pada masa pandemi covid-19 di SMK Muhammadiyah Pagaralam yang difokuskan pada kegiatan positioning menunjukkan bahwa implementasi kegiatan positioning di SMK Muhammadiyah pada masa pandemi covid-19 telah diterapkan dengan baik dalam keadaan pandemi covid-19. Hal ini dapat dilihat dari terpenuhinya beberapa indikator dalam implementasi strategi pemasaran jasa pendidikan pada kegiatan positioning yakni: pertama, lembaga pendidikan menyediakan atribut pemasaran atau media pemasaran, lembaga mendeskripsikan prospek bagi lulusan serta memberikan informasi yang valid terkait pembiayaan pendidikan pada kegiatan positioning. Adapun faktor pendukung kegiatan positioning pada masa pandemi covid-19 ini yakni: latar belakang pendidikan. Dari hasil penelitian diketahui bahwa pendidik dan civitas akademik memiliki latar belakang yang relevan dengan bidang yang kerjakan, selain itu SMK Muhammadiyah juga memiliki sarana dan prasarana yang memadai hal lainnya yang menjadi faktor pendukung adalah letak sekolah yang strategis dan mudah dijangkau oleh konsumen pendidikan. Sedangkan faktor penghambat adalah penetapan harga atau biaya pendidikan yang harus mampu bersaing pada masa pandemi covid-19, penawaran produk pendidikan juga mengalami kesulitan pada masa pandemi covid-19 dikarenakan keterbatasan akses untuk melakukan kegiatan promosi.
\end{abstract}

Kata kunci: pemasaran jasa pendidikan, strategi positioning 


\section{PENDAHULUAN}

Perkembanagan teknologi menuntut lembaga pendidikan perlu merancang strategi agar dapat menentukan sasaran pasar yang tepat. Sehingga lembaga pendidikan dapat mempermudah menyesuaikan antara produk yang dihasilkan dengan sasaran lembaga pendidikan. Selain itu, strategi yang dirancang lembaga juga dapat mempermudah lembaga pendidikan dalam menjalankan strategi yang telah direncanakan secara efektif. Maka dari itu, lembaga pendidikan perlu membuat dan menerapkan strategi pemasaran jasa pendidikan terutama dalam kegiatan positioning agar dapat mempermudah lembaga untuk mencapai tujuan yang telah ditetapkan.

Menurut Imam Machali pemasaran merupakan suatu manajerial dari suatu lembaga yang melibatkan kegiatan-kegiatan penting yang memungkinkan individu dan kelompok untuk mendapatkan suatu kebutuhan dan keinginan melalui suatu pertukaran antara suatu pihak dengan pohak lain dengan tujuan untuk mengembangkan hubungan yang baik dari pertukaran tersebut. Menurut Imam machali proses pemasaran sangat dipengaruhi oleh berbagai faktor seperti faktor sosial, politik, budaya, ekonomi dana menejerial. Akibat dari pengaruh tersebut maka individu tersebut mendapatkan suatu kebutuan dan keinginan mereka dengan menciptakan, menawarkan dan bertukar sesuatu yang bernilai satu sama lain (Mujamil Qomar, 2016).

Pemasaran adalah suatu proses perencanaan dan menjalankan konsep, harga, promosi dan distribusi sejumlah ide, barang, dan jasa untuk menciptakan pertukaran yang mampu memuaskan tujuan individu dan organisasi (Imam Faizin, 2017). Dalam konteks pendidikan kegiatan pemasaran jasa pendidikan dilakukan melalui kegiatan menawarkan mutu layanan intelektual dan pembentukan watak secara menyeluruh, karena pendidikan bersifat lebih kompleks yang dilaksanakan dengan penuh tanggung jawab, sehingga produk yang dihasilkan dapat mengacu kedepan, membina kehidupan warga negara dan generasi penerus dimasa yang akan datang. Adapun fungsi kegiatan pemasaran dalam lembaga pendidikan adalah untuk membentuk citra baik terhadap lembaga dan menarik minat calon peserta didik. Oleh karena itu pemasaran lembaga harus berorientasi pada "pelanggan" yang didalam konteks lembaga pendidikan disebut dengan peserta didik/siswa. Salah satu komponen utama yang harus dilakukan pada kegiatan pemasaran jasa pendidikan adalah kegiatan positioning. Menurut Kristanto positioning adalah suatu tindakan yang dilakukan oleh suatu lembaga atau perusahaan untuk mempromosikan produk yang dimilikinya kepada publik untuk menarik minat publik terhadap produk yang dtawarkan oleh lembaga. 
Dalam kegiatan positioning ini lembaga berusaha untuk mempengaruhi persepsi konsumen yang menjadi target atau sasaran lembaga untuk mempercayai produk yang ditawarkan (Jajat Kristanto, 2013). Dalam dunia pendidikan yang menjadi produk adalah program sekolah sedangkan, konsumen adalah masyarakat. Kegiatan positioning ini berhubungan dengan kepercayaan dan keyakinan masyarakat akan produk yang dihasilkan oleh lembaga pendidikan tersebut. Kegiatan positioning ini digunakan lembaga untuk memposisikan lembaga secara baik kepada masyarakat baik itu mengenai produk yang dihasilkan, citra baik lembaga maupun hal lain yang dapat menarik perhatian masyarakat untuk dapat memasukkan anaknya ke lembaga tersebut. Menurut Hasan terdapat beberapa indikator pelaksanaan kegiatan Positioning yakni:

a. Media pemasaran (Atribut) artinya lembaga pendidikan menggunakan suatu media baik itu media elektronik maupun media cetak dengan tujuan untuk mengenalkan dan memberikan informasi lengkap terkait dengan visi \& misi lembaga dan keunggulan lembaga pendidikan.

b. Penggunaan (Prospek bagi alumni) strategi ini merupakan suatu kegiatan dimana lembaga mendeskripsikan terkait dengan kebutuhan konsumen pendidikan tersier (instansi, perusahaan,perguruan tinggi dll) terhadap suatu bidang kejuruan yang dipilih oleh konsumen pendidikan primer(calon peserta didik)

c. Harga dan kualitas artinya disini lembaga pendidikan memberikan informasi terkait pembiayaan pendidikan kepada konsumen pendidikan dan meyakinkan konsumen pendidikan bahwasanya dengan pembiayaan yang ada konsumen pendidikan akan diberikan kualitas pendidikan yang bagus seperti sarana prasarana yang memadai.Persaingan artinya disini lembaga pendidikan memberikan perbandingan terhadap lembaga pendidikan pesaing yang menjadi titik acuan . strategi ini secara eksplisit mampu memposisikan lembaga pendidikan untuk melawan lembaga pendidikan yang kompetitor (Ali Hasan, 2015).

Pada penelitian Tika Novi Aliyanti yang berjudul "Implementasi Strategi STP (Segmentasi, Targeting, potisioning) di PT. Mina Wisata Islami Surabaya". Penelitian ini bertujuan untuk menggambarkan Implementasi Strategi STP di PT. Mina Wisata Islami Surabaya dan untuk menggambarkan faktor pendukung dan penghambat implementasi STP. penelitian ini menggunakan pendekatan kualitatif dengan jenis penelitian deskriptif (Tika Novi Aliyanti, 2019). Persamaan antara penelitian ini dengan penelitian sebelumnya terletak pada objek yang akan dikaji yakni implementasi pemasaran produk atau jasa. 
Sedangkan perbedaannya terletak pada bidang yang akan dikaji. Pada penelitian tika penelitian dilakukan pada bidang usaha yakni PT. Mina Wisata Islami, sedangkan pada penelitian ini akan dilakukan pada bidang pendidikan yakni Sekolah Menengah Kejuruan serta dalam penelitian ini peneliti memfokuskan penelitian pada kegiatan Positioning dalam implementasi pemasaran jasa pendidikan.

Kegiatan positioning ini mencangkup bagaimana strategi yang tepat dalam memenangkan persaingan pasar pendidikan sehingga lembaga pendidikan harus mampu memberikan perbandingan baik itu dari segi kualitas maupun kuantitas kepada pelanggan pendidikan terhadap produk yang dihasilkan oleh lembaga pendidikan sehingga membuat masyarakat lebih yakin untuk memilih lembaga pendidikan yang ditawarkan. Kegiatan positioning dilakukan di SMK Muhammadiyah dengan tujuan untuk menampilkan dan menonjolkan tampilan fisik terhadap produk yang dihasilkan dan meyakinkan konsumen pendidikan bahwa produk yang ditawarkan oleh SMK Muhammadiyah Pagar Alam berbeda dengan produk yang dihasilkan oleh lembaga pendidikan lainnya sehingga mendapatkan perhatian khusus dari konsumen pendidikan. Kegiatan positioning ini juga dilakukan oleh SMK Muhamaddiyah Pagar Alam sebagai strategi pemasaran jasa pendidikan untuk menarik minat konsumen pendidikan yakni siswa/siswi yang berasal dari SMP/MTs baik swasta maupun negeri baik dari dalam daerah maupun luar daerah. SMK Muhammadiyah merupakan salah satu sekolah menengah kejuruan yang berstatus swasta di kota Pagar Alam yang berdiri sejak tahun 1989. Sekolah ini memiliki 6 kejuruan yakni Multimedia, akuntansi, otomatisasi tata kelola perkantoran, teknik komputer jaringan, teknik bisnis sepeda motor dan farmasi. Sejak tahun berdirinya SMK Muhammadiyah selalu mengalami peningkatan jumlah peserta didik, namun banyaknya sekolah swasta dikota Pagar Alam menuntut sekolah untuk dapat memanfaatkan teknologi ditambah lagi dengan munculnya wabah covid-19 yang secara langsung dapat mempengaruhi kegiatan pemasaran jasa pendidikan, sehingga pemanfaatan teknologi dalam kegiatan pemasaran jasa menjadi suatu tindakan yang dinilai paling efektif untuk dapat menarik minat peserta didik. Namun jika dilihat dari kondisi masyarakat Masyarakat Pagar Alam yang mayoritas tidak mampu menguasai teknologi seperti Gadget dan laptop membuat sarana ini menjadi kurang efektif untuk dilakukan dan menyebabkan penurunan jumlah peserta didik pada PPDB tahun 2020. Hal inilah yang mendorong peneliti untuk mengetahui bagaimana strategi pemasaran terutama pada positioning yang dilakukan oleh SMK Muhammadiyah kota Pagar Alam sehingga dalam PPDB tahun 2020 terjadi penurunan jumlah peserta didik. 


\section{TINJAUAN PUSTAKA}

Secara sederhana kata implementasi dapat didefinisikan sebagai suatu kegiatan pelaksanaan atau penerapan. Sebagaimana yang ada didalam kamus Bahasa Indonesia, Implementasi memiliki makna penerapan. Browne dan Wildavsky memberikan pendapat bahwa " Implementasi ialah suatu perluasan dari sebuah aktivitas yang saling menyesuaikan". Adapun menurut Schuber dalam buku Arinda menjelaskan bahwa “implementasi merupakan suatu sistem rekayasa (Arinda Firdianti, 2018). Berdasarkan penjelasan diatas terlihat jelas bahwa implementasi merupakan suatu tindakan yang dilakukan berdasarkan suatu rencana yang telah disusun sebelumnya. Sedangkan Strategi menurut Kenneth R. Andrews merupakan suatu pola yang dibuat oleh sebuah lembaga agar dapat dengan mudah mengambil keputusan. Hal ini senada dengan pendapat Lesser Robert Bittel dalam buku Abdul Manap yang menyatakan bahwa strategi bermakna sebagai sebuah rencana yang bersifat fundamental yang dilakukan untuk mencapai tujuan suatu lembaga/instansi (Abdul Manap, 2016). Berdasarkan penjabaran tersebut dapat kita tarik kesimpulan bahwa strategi adalah suatu cara yang dapat digunakan oleh suatu instansi/lembaga untuk mencapai tujuan dimasa yang akan datang.

Dalam penelitian ini implementasi strategi pemasaran yang dimaksud adalah pemasaran jasa pendidikan dalam kegiatan Positioning (Penentuan citra). Menurut Tjiptono Positioning memiliki makna bahwa suatu kegiatan pemasaran yang baik akan menghasilkan persepsi yang baik bagi para pelanggan. Artinya bahwa positioning ini merupakan suatu metode atau cara yang digunakan oleh suatu lembaga untuk menciptakan citra baik dari lembaga tersebut sehingga dapat menarik pelanggan dan calon pelanggan dari pesaing lainnya (Fandy Tjiptono, 2019). Don E berpendapat bahwa Positioning adalah suatu cara ataumetode yang dilakukan oleh lembaga untuk meningkatkan produk dan menarik pelanggan. Dalam kata lain positioning digunakan oleh suatu lembaga agar dapat memenuhi keinginan konsumen dalam kategori yang lain (Kristanto).

Menurut Mohammad Dimyanti kegiatan positioning bertujuan untuk menempatkan nama lembaga dalam pikiran konsumen pendidikan melalui kompetensi, prestasi dll yang mampu memaksimalkan potensi manfaat lembaga pendidikan (Mohamad Dimyati, 2018).

Menurut Hasan terdapat beberapa indikator pelaksanaan kegiatan Positioning yakni:

a. Media pemasaran (Atribut) artinya lembaga pendidikan menggunakan suatu media baik itu media elektronik maupun media cetak dengan tujuan untuk mengenalkan dan 
memberikan informasi lengkap terkait dengan visi \& misi lembaga dan keunggulan lembaga pendidikan.

b. Penggunaan (Prospek bagi alumni) strategi ini merupakan suatu kegiatan dimana lembaga mendeskripsikan terkait dengan kebutuhan konsumen pendidikan tersier (instansi, perusahaan,perguruan tinggi) terhadap suatu bidang kejuruan yang dipilih oleh konsumen pendidikan primer (calon peserta didikHarga dan kualitas artinya disini lembaga pendidikan memberikan informasi terkait pembiayaan pendidikan kepada konsumen pendidikan dan meyakinkan konsumen pendidikan bahwasanya dengan pembiayaan yang ada konsume pendidikan akan diberikan kualitas pendidikan yang bagus seperti sarana prasarana yang memadai.

c. Persaingan artinya disini lembaga pendidikan memberikan perbandingan terhadap lembaga pendidikan pesaing yang menjadi titik acuan . strategi ini secara eksplisit mampu memposisikan lembaga pendidikan untuk melawan lembaga pendidikan yang kompetitor.

Abdul manap mengemukakan bahwa terdapat beberapa prosedur strategi penetapan Positioning yakni sebagai berikut;

a. Penentuan posisi manfaat;

Produk yang dimiliki lembaga pendidikan dapat diposisikan sebagai pemimpin dalam suatu manfaat tertentu. Penciptaan suatu produk (dalam hal ini produk berarti jurusan/ kejuruana yang akan diadakan) tidak terlepas dari manfaat dan kegunaan yang kan di dapatkan oleh konsumen pendidikan yakni calon peserta didik (Sandy Wulan Karamoy, 2013). oleh karena itu proses penentuan sebuah produk dalam lembaga pendidikan yang akan ditawarkan kepada konsumen pendidikan perlu dipertimbangkan dari segi manfaatnya. Jika produk yang dihasilkan oleh lembaga pendidikan memiliki manfaat terbaik bagi konsumen pendidikan, maka tentunya suatu lembaga pendidikan akan memiliki kedudukan tertinggi dalam memenangkan persaingan pasar lembaga pendidikan.

b. Penentuan posisi menurut pesaing;

Lembaga pendidikan harus mampu memposisikan produk yang terbaik dari pada pesaing lainnya (Precylia Cyndi Kembuan, Lisbeth Mananeke, and Agus Supandi Soegoto, 2014). Tentunya setiap lembaga pendidikan pasti dihadapkan oleh pesaing lainnya oleh sebab itu hendaknya setiap lembaga pendidikan dapat menentukan posisi produk 
pendidikan yang terbaik untuk menghadapi pesaing agar tetap memiliki citra unggul dimata konsumen pendidikan.

c. Penentuan posisi berdasarkan penggunaan atau penerapan;

Lembaga pendidikan harus mempu memposisikan lembaga pendidikannya sebagai lembaga pendidikan yang terbaik untuk sejumlah pengguna atau penerapan dalam dunia kerja (Kembuan, Mananeke, and Soegoto). Penentuan sebuah produk dalam lembaga pendidikan berdasarkan pada kebutuhan setiap konsumen pendidikan tersier (Perusahaan dan dunia kerja) setiap lembaga pendidikan memiliki berbagai produk (jurusan) yang berkualitas untuk ditawarkan kepada setiap konsumen pendidikan yakni calon peserta didik dan wali murid peserta didik. Kebutuhan setiap konsumen pendidikan mengharuskan setiap lembaga pendidikan dapat menciptakan berbagai macam prosuk (jurusan) yang disesuaikan dengan kebutuhan konsumen pendidikan.

d. Penempatan posisi berdasarkan kualitas atau harga.

Lembaga pendidikan harus mampu memposisikan produk dengan harga dan kualitas yang terbaik. Lembaga pendidikan perlu memperhatikan kualitas suatu produk yang akan ditawarkan kepada konsumen. Harga suatu produk (jurusan) dari lembaga pendidikan harus disesuaikan dengan kualitas yang akan diberikan juga kepada konsumen pendidikan (Karamoy). Jadi penentuan kualitas suatu produk yang ditawarkan akan berpengaruh pada harga yang akan ditentukan pada nantinya.

Selain itu Rahmi Yuliana (2013) mengungkapkan, bahwa terdapat beberapa langkah yang harus dipahami oleh lembaga dalam implementasi strategi positioning yakni sebagai berikut;

a. Mengidentifikasi keunggulan kompetitif;

Jika suatu lembaga pendidikan dapat menempatkan posisi lembaganya untuk memberikan nilai superior kepada sasaran lembaga pendidikan yang telah dipilih, maka lembaga pendidikan tersebut dapat memperoleh keunggulan kompetitif tersendiri dimata konsumen pendidikan. Dalam mendapatkan keunggulan bersaing, lembaga pendidikan perlu melakukan kegiatan diferensiasi atas penawaran terhadap konsumen pendidikan yang berbeda kemudian dibandingkan dengan penawaran dari pesaing( lembaga pendidikan lainnya) (Michael Adiwijaya, 2007).

b. Penawaran suatu produk;

Dalam proses penawaran suatu produk lembaga pendidikan perlu menyediakan suatu alasan mengapa konsumen pendidikan dapat merasakan bahwa produk dari lembaga 
pendidikan yang ditawarkan lebih baik dari pada produk yang dihasilkan dari lembaga pendidikan lainnya, Yuliana juga mengungkapkan, bahwa Analisis Strategi Pemasaran Pada Produk Sepeda Motor Matik Berupa Segmentasi, Targeting, Dan Positioning Serta Pengaruhnya Terhadap Keputusan Pembelian Konsumen Di Semarang.

c. Melakukan evalusi terhadap respon konsumen;

Sebuah lembaga pendidikan perlu melakukan proses evaluasi terhadap respon dari target pasar lembaga pendidikan sehingga lembaga pendidikan dapat membuat suatu inovasi baru dalam penetapan strategi yang akan dilakukan (Yuliana).

Menurut Mohammad Dimyanti proses Positioning dapat dialkukan melalui langkahlangkah berikut:

Mendefinisikan kesegmen pasar mana suatu produk lembaga pendidikan akan disaingkan. Artinya lembaga pendidikan mendefinisikan dan menelaah lembaga pendidikan yang termasuk kedalam segmen pasar yang memiliki potensi besar untuk masuk ke lembaga pendidikan yang ditawarkan.

a. Mengumpulkan persepsi informasi dari konsumen lembaga pendidikan tentang persepsi masyarakat terkait dengan jurusan yang ditawarkan oleh lembaga pendidikan.

b. Mengukur seberapa jauh persepsi baik konsumen pendidikan terhadap produk yang dihasilkan oleh lembaga pendidikan.

c. Mengukur seberapa besar pasar produk pesaing lembaga pendidikan.

Dalam kegiatan pemasaran baik itu pemasaran barang ataupun jasa Positioning merupakan suatu cara yang ditempuh oleh pemasar dalam membangun citra atau identitas yang baik di fikiran masyarakat terhadap produk yang akan dihasilkan oleh suatu lembaga ataupun instansi.

\section{METODE}

Penelitian ini menggunakan pendekatan kualitatif. Sumber data dalam penelitian ii adalah sumber data Primer yang didapatkan dari hasil wawancara dengan kepala sekolah, waka kurikulum, waka kesiswaan dan ketua tim promosi, selian itu data primer yang digunakan adalah hasil observasi yang dilakukan di SMK Muhammadiyah Pagar Alam, observasi digunakan adalah observasi langsung dimana peneliti ikut berpartisipasi dalam kegiatan positioning di SM Muhammadiyah Pagar Alam. 
Teknik analisis data yang digunakan dalam penelitian ini adalah model Miles and Huberman dapat dilakukan dengan langkah awal yakni melakukan reduksi data (Data Reduction), Penyajian Data dan Verifikasi data (D R Sugiyono, 2009).

\section{HASIL PENELITIAN}

Penelitian ini dilakukan pada tanggal 25 Maret 2021 sampai tanggal 25 April 2021 di SMK Muhammadiyah Pagar Alam. Penelitian ini berfokus pada kegiatan Implementasi positioning jasa pendidikan di SMK Muhammadiyah Pagar Alam. Penelitian ini dilakukan sebanyak 4 kali pertemuan, pertama peneliti melakukan observasi kegiatan pemasaran jasa pendidikan di SMK Muhammadiyah Pagar Alam, pertemuan kedua peneliti mewawancarai kepala sekolah, waka kesiswaan, waka kurikulum, ketua tim sosialisasi dan wali murid dari siswa/i di SMK Muhammadiyah Pagar Alam. Pertemuan ketiga peneliti mengikuti kegiatan positioning dalam pemasaran jasa pendidikan dan mendokumentasikan kegiatan tersebut. Kemudian pada pertemuan keempat peneliti mengumpulkan data-data yang mendukung penelitian di SMK Muhammadiyah Pagar Alam dari penelitian ini penelliti mendapatkan hasil sebagai berikut:

\section{Implementasi strategi Pemasaran Jasa Pendidikan di SMK Muhammadiyah Pagar Alam}

Menurut Hasan Dalam implementasi kegiatan Positioning berpendapat bahwa terdapat beberapa indikator yang harus dipenuhi seperti Adanya Media Pemasaran (Atribut pemasaran), lembaga mendeskripsikan kegunaan (prospek kedepan bagi Lulusan), lembaga pendidikan memberikan informasi terkait dengan pembiayaan pendidikan (penentuan harga dan kualitas) (Hasan). Hal ini dibenarkan oleh Sadlan selaku Kepala sekolah yang menyatakan bahwa dalam implementasi kegiatan positioning lembaga pendidikan harus menyiapkan media atau atribut yang digunakan sebagai alat untuk mempermudah lembaga pendidikan memasarkan lembaga pendidikannya, kemudian mendeskripsikan prospek kedepan bagi lulusan juga merupakan faktor yang paling penting dalam menarik minat peserta didik setelah itu barulah lembaga pendidikan memberikan uraian terkait dengan biaya pendidikan yang harus disiapkan oleh konsumen pendidikan dan meyakinkan bahwa harga tersebut telah sepadan degan kualitas yang didapatkan oleh konsumen pendidikan selama menempuh pendidikan di SMK Muhammadiyah Pagar Alam (Sadlan, 2021). Hal ini juga diperkuat oleh data observasi yang menunjukkan bahwa SMK Muhammadiyah telah mempersiapkan secara matang terkait dengan implementasi strategi Pemasaran Jasa Pendidikan pada masa Pandemi Covid-19 di SMK Muhammadiyah Pagar Alam yang 
difokuskan pada kegiatan positioning yang menunjukkan bahwa SMK Muhammadiyah mengadakan persiapan berupa rapat PPDB, membentuk panitia promosi PPDB, melakukan kegiatan-kegiatan sosial dengan memenuhi protokol kesehatan kepada masyarakat kurang mampu, pada saat kegiatan promosi SMK Muhammadiyah memberikan gambaran secara jelas terkait dengan prospek kedepan bagi lulusan dan meyakinkan bahwa biaya yang ditetapkan lembaga telah sesuai dengan kualitas pendidikan, kemudian untuk media atau atribut yang digunakan dalam kegiatan Pemasaran Jasa pendidikan SMK Muhammadiyah menyiapkan media yang digunakan untuk promosi baik itu media cetak ataupun pemanfaatan media sosial seperti FB, Youtube, Instagram dan Telegram (Ade Wulandari, 2021).

\section{Faktor yang mempengaruhi Implementasi Strategi positioning}

Menurut Karsini terdapat 3 faktor yang menjadi pendukung implementasi kegiatan positioning di SMK Muhammadiyah Pagar Alam yakni: pertama, Latar belakang pendidikan yang ditempuh oleh tenaga pendidik dan kependidikan relevan dengan bidang yang diajarkan, kedua, sarana dan prasarana pendidikan yang lengkap seperti tersedianya laboratorium dan ruang praktik bagi setiap jurusan, banyaknya ruang kelas, adanya masjid, kantin, apotik dll dan ketiga lokasi sekolah yang strategis berada dipusat kota Pagar Alam menjadikan SMK Muhammadiyah Pagar Alam mudah dijangkau oleh konsumen pendidikan yang berdomisili di kota Pagar Alam dan konsumen pendidikan akan lebih mudah mengetahui berbagai informasi terkait dengan keunggulan yang ada di SMK Muhammadiyah Pagar Alam. Kemudian terdapat 2 faktor yang menjadi penghambat dalam implementasi Strategi pemasaran Jasa pendidikan Pada masa pandemi covid-19 yang difokuskan pada kegiatan positioning yakni penetapan harga atau biaya pendidikan oleh pihak sekolah dikarenakan kondisi masyarakat yang mengalami kesulitan ekonomi pada masa pandemi covid-19 dan penawaran suatu produk yang berupa kegiatan promosi sekolah juga mengalami kendala (Karsini, 2021). Hal ini juga diperkuat oleh pernyataan bapak lasdi yang menyatakan bahwa terdapat beberapa faktor pendukung dalam implementasi strategi pemasaran jasa pendidikan khususnya pada kegiatan positioning yakni latar belakang pendidikan guru yang relevan dengan bidang keahlian yang diajarkan dan lokasi sekolah yang strategis sehingga warga yang bertempat tinggal disekitaran kota banyak yang masuk ke SMK Muhammadiyah ini, namun terdapat kendala terutama pada saat penawaran suatu produk yang mengalami kesulitan karena pada masa pandemi covid-19 ini kegiatan penawaran produk tidak dapat disampaikan langsung kepada konsumen pendidikan atau 
dalam kata lain lembaga tidak dapat bertemu secara langsung kepada calon peserta didik melainkan hanya dengan guru sehingga hal tersebut kurang efektif dalam menarik minat peserta didik (Lasdi, 2021). Pernyataan diatas diperkuat oleh hasil dokumentasi yang menunjukkan bahwa SMK Muhammadiyah terletak di tengah-tengah kota Pagar Alam sehingga konsumen pendidikan sangat mudah mengakses segala informasi yang dibutuhkan terkait dengan kegiatan yang ada di SMK Muhammadiyah Pagar Alam.

Dengan demikian berdasarkan hasil observasi, wawancara dan dokumentasi menunjukkan bahwa Implementasi strategi Pemasaran Jasa pendidikan di SMK Muhammadiyah Pagar Alam telah berjalan dengan baik hal ini dibuktikan dengan terpenuhinya beberapa komponen yang menjadi indikator keberhasilan implementasi strategi Pemasaran Jasa pendidikan yang difokuskan pada kegiatan Positioning di SMK Muhammadiyah Pagar Alam.

\section{PEMBAHASAN}

\section{Implementasi Strategi Pemasaran Jasa Pendidikan}

Dari hasil penelitian yang dilakukan berdasarkan kegiatan Wawancara dan Observasi terungkap bahwa lembaga pendidikan SMK Muhammadiyah Pagar Alam telah menerapkan kegiatan positioning secara baik. Kegiatan positioning pada masa pandemi Covid-19 dilakukan secara terbatas dengan memenuhi indikator-indikator implementasi kegiatan positioning seperti sekolah atau lembaga pendidikan menyediakan atribut pemasaran jasa pendidikan seperti Brosur, banner dan sosial media, setelah itu sekolah melakukan kegiatan promosi jasa pendidikan ke sekolah-sekolah yang menjadi target pendidikan. Menurut Hasan media pemasaran (Atribut) artinya lembaga pendidikan menggunakan suatu media baik itu media elektronik maupun media cetak dengan tujuan untuk mengenalkan dan memberikan informasi lengkap terkait dengan visi \& misi lembaga dan keunggulan lembaga pendidikan seperti yang diungkapkan Hasan. Kemudian mendeskripsikan prospek kedepan bagi lulusan dengan menunjukkan data-data alumni SMK Muhammadiyah yang telah diterima di perguruan tinggi negeri ataupun di perusahaan atau klinik-klinik kesehatan. Penggunaan (Prospek bagi alumni) strategi ini merupakan suatu kegiatan dimana lembaga mendeskripsikan terkait dengan kebutuhan konsumen pendidikan tersier (instansi, perusahaan, perguruan tinggi) terhadap suatu bidang kejuruan yang dipilih oleh konsumen pendidikan primer (calon peserta didik) (Hasan). Setelah itu SMK 
Muhammadiyah Pagar Alam juga mendeskripsikan harga secara detail kepada calon peserta didik atau konsumen pendidikan melalui brosur yang dibagikan.

Dalam kegiatan pemasaran jasa pendidikan lembaga pendidikan harus memberikan informasi terkait pembiayaan pendidikan kepada konsumen pendidikan dan meyakinkan konsumen pendidikan bahwasanya dengan pembiayaan yang ada konsumen pendidikan akan diberikan kualitas pendidikan yang bagus seperti sarana prasarana yang memadai (Hasan).

\section{Kegiatan positioning dipengaruhi oleh Sarana dan Prasarana, Lokasi dan Latar pendidikan Guru atau civitas Akademik}

Hasil analisis pada penelitian didapatkan bahwa kegiatan Positioning ini dipengaruhi oleh kelengkapan sarana dan prasarana lembaga pendidikan seperti ruang laboratorium, jumlah ruang kelas, jumlah ruang praktik, perpustakaan, tempat ibadah, ruang guru dan kelengkapan alat dari laboratorium masing-masing jurusan, selain itu kegiatan positioning juga dipengaruhi oleh lokasi sekolah yang strategis sehingga masyarakat atau konsumen pendidikan lebih muda mengakses informasi terkait hal-hal yang ada di lembaga pendidikan SMK Muhammadiyah, kemudian latar belakang pendidikan guru juga dapat mempengaruhi perspektif masyarakat terhadap kualitas lembaga pendidikan, dimana masyarakat yakin bahwa dengan latar belakang pendidikan guru yang relevan dengan bidang yang dikerjakan akan mempengaruhi proses pelayanan intelektual yang diberikan oleh lembaga pendidikan.

\section{Kegiatan Positioning dipengaruhi oleh penetapan harga dan penawaran produk}

Dari hasil penelitian terungkap bahwa pada masa pandemi covid-19 lembaga pendidikan mengalami kesulitan dalam hal penetapan harga pendidikan, artinya pada masa pandemi covid-19 ini lembaga pendidikan harus mampu menganalisis dan menyesuaikan antara biaya lembaga pendidikan dengan kondisi ekonomi calon konsumen pendidikan kemudian pada masa pandemi covid-19 lembaga pendidikan juga mengalami kendala pada hal penawaran produk pendidikan, pada masa panemi covid-19 lembaga pendidikan tidak dapat melakukan kegiatan positioning secara optimal dikarenakan adanya keterbatasan akses untuk bertemu dengan calon peserta didik sehingga dalam kegiatan promosi tim promosi melakukan kegiatan promosi melalui perantara wali kelas atau guru disekolah tersebut. Dalam proses penawaran suatu produk lembaga pendidikan perlu menyediakan suatu alasan mengapa konsumen pendidikan dapat merasakan bahwa produk dari lembaga 
pendidikan yang ditawarkan lebih baik dari pada produk yang dihasilkan dari lembaga pendidikan lainnya (Yuliana).

\section{KESIMPULAN}

Implementasi Strategi pemasaran jasa pada masa pandemi covid-19 yang difokuskan pada kegiatan positioning telah berjalan dengan baik. Hal ini dibuktikan dari terpenuhinya indikator implementasi kegiatan positioning yang terdiri dari lembaga pendidikan menyediakan media pemasaran jasa atau atribut pemasaran yang berupa media cetak dan pemanfaatan teknologi atau media sosial seperti intagram, Youtube dan facebook kemudian lembaga pendidikan mendeskripsikan kegunaan pendidikan (prospek kedepan bagi alumni) agar calon peserta didik termotivasi untuk tergabung dalam lembaga pendidikan tersebut, yang terakhir SMK Muhammadiyah Pagar Alam juga mendeskripsikan biaya yang dibutuhhkan selama sekolah di SMK Muhammadiyah Pagar alam. Namun kegiatan tersebut tidak terlepas dari beberapa faktor pendukung dan penghambat, adepun faktor pendukung dari implementasi straegi pemasaran jasa pendidikan pada masa pendemi covid-19 di SMK Muhammadiyah Pagar Alam adalah latar belakang pendidikan yang di miliki guru dan civitas akademik, sarana dan prasarana pendidikan yang memadai dan lokasi sekolah yang strategis sehingga mempermdah sekolah untuk melakukan kegiatan positioning. Adapun faktor yang menghambat kegiatan positioning pada masa pandemi covid-19 ini adalah penetapan harga atau biaya pendidikan dan penawaran produk pendidikan yang terkendala karena adanya pembatasan interaksi langsung pada masa pandemi covid-19. 


\section{DAFTAR PUSTAKA}

Ade Wulandari. (2021). Observasi. SMK Muhammadiyah Pagar Alam.

Adiwijaya, Michael. (2007). Analisa Strategi Reposisi Merek Dalam Persaingan Pasar. Jurnal Manajemen Pemasaran, 2(2).

Aliyanti, Tika Novi. (2019). Implementasi Strategi STP (Segmentasi, Targeting, Positioning) di PT. Mina Wisata Islami Surabaya. UIN Sunan Ampel Surabaya.

Dimyati, Mohamad. (2018). Pendekatan Hayati: Strategi Pemasaran Untuk Menghadapi Persaingan Yang Dinamis.

Faizin, Imam. (2017). Strategi Pemasaran Jasa Pendidikan Dalam Meningkatkan Nilai Jual Madrasah. Madaniyah, 7(2): 261-83.

Firdianti, Arinda. (2018). Implementasi Manajemen Berbasis Sekolah Dalam Meningkatkan Prestasi Belajar Siswa. Gre Publishing.

Hasan, Ali. (2015). Tourism Marketing.

Karamoy, Sandy Wulan. (2013). Strategi Segmenting, Targeting Dan Positioning Pengaruhnya Terhadap Keputusan Konsumen Menggunakan Produk KPR BNI Griya. Jurnal EMBA: Jurnal Riset Ekonomi, Manajemen, Bisnis Dan Akuntansi, 1(3).

Karsini. "Wawancara.” Pagar Alam: SMK Muhammadiyah Pagar Alam, 2021.

Kembuan, Precylia Cyndi, Lisbeth Mananeke, and Agus Supandi Soegoto. (2014). Analisis Segmentasi, Targeting Dan Positioning Pembiayaan Mobil Pada PT. Adira Dinamika Multifinance Tbk Cabang Manado. Jurnal EMBA: Jurnal Riset Ekonomi, Manajemen, Bisnis Dan Akuntansi, 2(3).

Kristanto, Jajat. (2013). Manajemen Pemasaran Internasional: Sebuah Pendekatan Strategi.

Lasdi. "Wawancara." SMK Muhammadiyah Pagar Alam, 2021.

Manap, Abdul. (2016). Revolusi Manajemen Pemasaran. Jakarta: Mitra Wacana Media.

Qomar, Mujamil. (2016). Manajemen Pendidikan Islam.

Sadlan. "Wawancara." SMK Muhammadiyah Pagar Alam, 2021.

Sugiyono, D R. (2009). Metodologi Penelitian Pendidikan. Bandung Alf.

Tjiptono, Fandy. (2019). Pemasaran Jasa.

Yuliana, Rahmi. (2013). Analisis Strategi Pemasaran Pada Produk Sepeda Motor Matik Berupa Segmentasi, Targeting, Dan Positioning Serta Pengaruhnya Terhadap Keputusan Pembelian Konsumen Di Semarang. JURNAL STIE SEMARANG (EDISI ELEKTRONIK), 5(2): 79-92. 
